\title{
DISCREDITED FEMALE CHARACTERS, OR “GONE WITH THE WOMEN". A DESCRIPTIVE ESSAY OF MARGINALIZED FEMININITY IN CORMAC MCCARTHY'S SELECTED NOVELS
}

One dare say that male is the norm or, say even stronger, humanity is viewed as masculine. For some it is obvious that men reckon culture and society as male. If society is 'male', then literature must also be 'male.' To go further, women used to be made to view the world from a masculine perception as well. Their intelligence and their judgement were always regarded with contempt by a male oriented society. Women were seen and treated more as complements to the men in their lives than as individuals or spiritual entities; they were depicted in literature as womanly, weak, duteous, and unintelligent. What seems to be fascinating to note is the whole range of male roles undergoing literary transformations, whereas female literary characters adhere to the classic modes. While male characters have been given free rein to be and become what they wish, women characters have been written to play and re-play the same limited themes. Thus, when the female character diverts from the stringent classification, more attention is then called to the purity of what the female character is supposed to be. The limitation of the women's stereotypes in literature is as invalidating as the confinement of the female in real life. Although many acknowledge women on equal terms, there are authors who have continued to write with the misguided perception that women are always inferior to men.

Among those writers, Cormac McCarthy, one of the greatest American contemporary novelists, takes a lead. He definitely glorifies the male world, whereas women are given, unquestionably, minor importance. All the same, Cormac McCarthy introduces female characters into his stories; they are of 'complicated' structure, often deprived of standardized qualities, with inclinations to dysfunction or self-destruction. Although the author gives women the possibility to form a female-male 
relationship, he strangles it after all. Therefore, McCarthy contextualizes male dominance over female characters and points out the diminished role of women. He goes against the current of social and literary equality, treating women as subsidiary.

Furthermore, McCarthy's novels outline several recurring patterns of portraying women as emotionless and absent mothers, "whores", and finally, female characters subjected to being repulsive figures, associated with danger or death. Those who carry symbols of death have dispositions to perish and, ultimately, vanish from the book's pages. One of the critics relating to McCarthy's All the Pretty Horses, the first instalment of The Border Trilogy, stated that the male characters' existence is free of routine, of money, of women who interact, or simply intrude on male life by offering plates laden with food, fresh laundry, and occasionally their bodies [Hage 2010: 169-170]. Another journalist pointed out that McCarthy's world is an existential one in which men face two choices - either to battle or to die; the female characters, meanwhile, cook, sew, sell themselves on the street [Bradfield 1993], or are mute, have no names, and thus, their existence is deficient or obscure, or relegated to the margin.

\section{Mute female characters}

The Crossing, the second instalment of the western trilogy, portrays a number of minor, nameless women among whom, there is a girl, who Billy and Boyd rescue from being raped. She appears in the story quite unexpectedly and disappears in the same manner. Boys and the girl form a pack, travel together, coexist. But she has no name, she says no word, she is the shadow of a visible embodied soul of a dead or non-existent person. And she will become one soon. As the entire world in The Crossing appears to be destructive, the girl has a lethal impact on Boyd as well. He elopes with the girl, leaving his brother behind, then runs the life of a villain and dies as a bandit or hero, cherished in Mexican corridos some time later. Yet the girl who imposed devastation on Boyd's life and made Billy in constant search for either his brother or his bones, is never given a name. The moment Boyd is removed from the pages of the story, so is the girl. However, Boyd presence is cultivated in his brother's memory. Billy cherishes every recollection of his brother, mourns his death, worships his remains. The nameless girl disappears, like many others in subsequent stories.

Cities of the Plain, the third and last part of the trilogy, features only four major female characters, of whom only one, Magdalena, is legitimately 
characterized enough to speak. Socorro, whose name means help, effectively raised Margaret Johnson McGovern and is Mac's housekeeper, but she rarely ever speaks; and, true to her name, she serves in a traditional function: to be subservient in a silent manner. The one-eye criada (maid) is Socorro's dark mirror, serving as Eduardo's housekeeper and Magdalena's surrogate mother, just as Socorro was Margaret's. Apart from her devoted service, she has not much to say. Although Margaret Johnson McGovern's existence is often mentioned, she is merely a ghost and a name, as she only functions in others memory. Billy's sister and grandmother, both named Margarita, correspond with Margaret's vision and function as ghostly, mute, and dead, long before the story proceeded.

These silent characters seem to form the stories' vistas, letting male protagonists develop their own literary scope and potential on the females' backgrounds. In McCarthy's novels women are crucial to binding the plots, but they never lead, only float on the books' pages. They lack any vigor and dynamism. They are nameless and speechless. Time in McCarthy's novels is reverted to an ancient dimension with women at the margin of societies. If literature is to mirror the society, so the concept of women's presence and importance is still to be reformed, rewritten, and reread. But this definitely does not occur in McCarthy's world. Picturing women as specific, anonymous function-types deepens the discrepancy between male and female characters, giving more attention and favour to male ones. It causes further inclinations of distancing from female characters, or even portraying them in a contorted mode. For example, mothers, undeniable icons of caring love and devotion, are seen in a false mirror, since McCarthy leaves little of their motherhood.

\section{Obviation of mothers}

As Erik Hage claims, "McCarthy's representation of mothers in his work is ambivalent at best" [Hage 2010: 115]. In some words, mothers litter his books with their cold and absent presence. In one of the first novels, The Orchard Keeper, the main character is brought up in a cold, harsh way under pressure put on him. His mother implants a duty to avenge his father: "You [are] going to hunt him out. When you're old enough. Going to find the man that took away your daddy" [McCarthy 1965: 66]. Her remoteness from her son makes John Wesley, the leading protagonist, seek out a surrogate parental relationship with a man from the village, a bootlegger Marion Sylder. The child subconsciously yearns for balance in his life, where an adult serves 
the role of protector and carer. Yet, what cannot be substituted is maternal love and affection, which Marion Sylder is incapable of giving. But neither is the mother of the boy. McCarthy portrays her as repellent, through an unflattering physical description: "Eyes (...) blink when she swallows like a toad's. Lids wrinkled like walnut hulls. Her grizzled hair gathered, tight, a helmet of zinc wire" [McCarthy 1965: 61].

In the subsequent novel, Outer Dark, there are no parents to protect and guide, only a brother and sister and unwanted motherhood out of kinship closeness. Although Rinthy, the main character of the novel, the only truly developed female protagonist in all McCathy's stories, attempts to salvage her baby, she is devoid of the possibility to raise her child. She is unable to perform her motherhood. Culla, her brother and the baby's father, takes it away and abandons it in the woods. However, it is Rinthy who faces the consequences of her relevant affinity. McCarthy gives her the chance to develop her motherly feelings, as she awakens and departs in search of the baby to avert her fate, to break out of darkness. There is no redemption, though. Like Culla, Rinthy is perceived as a doomed character, for she broke a taboo. Inevitably, she is punished as she encounters her charred grilled baby partly devoured by manlike, inhuman beasts only to foreshadow the remains of another burnt child in the apocalyptic destruction of the world in The Road. To our horror, the child is to be annihilated by its desperate parents.

In All the Pretty Horses John Grady Cole's mother abandons and symbolically betrays him by divorcing his father and selling his grandfather's ranch. Her presence is encountered only once when John tries to meet her before departing for Mexico. She's an actress, lives independently, far from her husband and her son. While observing his mother on the stage, John bears a grudge and feels no bond with her. Therefore, the boy distances himself from his mother, casts her from his life. Neither does he greet her after the performance nor meet her. He does not mention her existence ever after. Traces of her appear in Cities of the Plain, when Billy suggests asking John's mother for financial support. "What's my mother got to do with anything?" [McCarthy 1998: 217], the boy replies. The main female character in All the Pretty Horses, Alejandra, experiences quite a similar situation. Her mother fails her role. She lives in Mexico City, with no husband, no daughter.

The default of mothers deepens considerably in Child of God, since it is clear that Lester Ballard's "mother had run off" [McCarthy 1973: 21] abandoning the future necrophiliac and killer alone with a father who will 
soon hang himself. When it comes to the child in Blood Meridian or the Evening Redness in the West, the boy is also left with an insufficient father after his mother dies. The father, an alcoholic, "never speaks her name, the child does not know it", illustrating a striking absence [McCarthy 1985: 3]. In The Crossing, Bill's mother is killed by the end of his first journey to Mexico; thus, she's not heard of for the rest of the story.

McCarthy's consistency in portraying mothers' non-existence, has its strongest representation in The Road, when the mother chooses to commit suicide rather than face the horrors of the post-apocalyptic world. Her break-up with her family is utterly cold. She does not want to see her son before leaving and explains that she has "taken a new lover" [McCarthy 2006: 57], referring to death. Her presence in the book is merely through vague memories: "She was gone and the coldness of it was her final gift" [McCarthy 2006: 58].

\section{Prostitutes - commodity women. Grotesque figures}

What some may find disturbing in McCarthy's fiction is not only women's rare presence or dysfunctional mothers, but female inclinations toward prostitution. "Goddamned old whore" - this is how Lester Ballard in Child of God tries to discredit a woman accusing him of rape [McCarthy 1973: 52]. In McCarthy's novels women seem to be "naturally" labelled and identified with the profession. Blood Meridian, or the Evening Redness in the West features only two women who speak in the novel. One of them is a prostitute the kid hires from among "the whole squadrons of whores" [McCarthy 1985: 332] in Fort Griffin. For that moment, females have no other function. They serve and are gone. In Cities of the Plain, Magdalena's name is a clear allusion to the biblical one, since her profession in the book, "nombre professional" [McCarthy 1998: 67], stands for an old euphemism for prostitution. Although Magdalena is portrayed sympathetically in comparison with other female characters, she is still simply displayed as a commodity. John Grady, who falls in love with her, tries to buy her from Eduardo, her pimp. Therefore having been treated as an object in the brothel, her salvation is subjected to a transaction. She is a thing to be bought.

In Suttree, the main character indulges himself living on his girlfriend's work. Joyce, the girl's name, defines herself through her profession, since it is what she serves for - sexual pleasure. She leaves for different cities to find a source of living, to be the only provider for the couple. But at the end of the relationship, she is ultimately labelled as "whore". In the scene 
of Suttree and Joyce's breakup, after she destroys the car windshield, "the officer looked down at Suttree and his whore" [McCarthy 1989: 410]. Thus, she is not even referred to by her name any more, only diminished to an unfaithful occupation.

The Road also uses the pattern of discrediting the female character, but to justify her suicide: "They are going to rape us and kill us and eat us and you won't face it (...), because I am done with my own whorish heart and I have been for a long time" [McCarthy 2006: 56-57]. Although she is not a prostitute, she claims the label. She feels unfit for motherhood, therefore must bear expulsion from the story.

Each of McCarthy's novel excludes the potentially significant female character and puts the burden of 'sin' on a woman's shoulder. In Cities of the Plain, Billy cradles John Grady's corpse in his arms and calls on God to witness the destruction brought by women as he disregards them and places the blame on them:

Goddamned whores, he said. He was crying and the tears ran on his angry face and he called out to the broken day against them all and he called out to God to see what was before his eyes. Look at this, he called. Do you see? Do you see? [McCarthy 1998: 261].

Women are also equated with grotesque figures, as reminders of the body's fatal decay. Magdalena in Cities of the Plain is an epileptic prostitute, while the woman appearing in the final pages of Blood Meridian is "a dark little dwarf of a whore" [McCarthy 1985: 332]. The most revolting of all is comparing a female character to meat. In Suttree, Jim Long refers to prospective sexual conquest as "cuntlets" [McCarthy 1989: 302], while in the other part "an enormous whore" is guilty of "porcine lechery" [McCarthy 1989: 74] as having an intimate encounter with a pig-size prostitute. When women are represented as meat, by implication they are meant to be butchered. In The Crossing the Mexican girl's would-be rapist informs Billy, "if they were old enough to bleed they were old enough to butcher" [McCarthy 1994: 209], as if foreseeing Magdalena's death in Cities of the Plain.

Death in McCarthy's narratives bears an unquestionably female representation. Ethel, the tattooed prostitute in Suttree, has "a part of a peacock, a wreath with the name Wanda and the words Rest in Peace 1972" [McCarthy 1989: 75]. These words will relate to Wanda Reese's, 
Suttree's underage girlfriend's, death. She is, as well, reduced to "sheared limbs and rags of meat" when a rock and sand slide crushes her [McCarthy 1989: 362]. Significantly, Suttree's perfect lover, young and uncomplicated, is too perfect to live. Even though Wanda is not a prostitute, her death is foretold on the body of one.

Apart from symbolic representations of death, women in McCarthy's books are simply put to death as a motif of permanent elimination. In The Road the mother undertakes the ultimate solution in the face of the helplessness of her family and her own existence, the destruction of the world and her inner weakness. Not only is the mother removed from the scenes of the story, but from the heart of her husband. The book echoes the situation gloomily when the father empties the contents of his wallet: "some money, credit card. His driver's license. A picture of his wife" [McCarthy 2006: 51]. The man lays his wife's photo "down in the road also" [McCarthy 2006: 51] and he and the boy leave. Not much time later he remembers the photograph and thinks "he should have tried to keep her in their lives in some way but he didn't know how" [McCarthy 2006: 54]. Her role has come to an end as mother, wife, or being.

The theme of the dead beloved is presented distinctively not only in The Road, but in Cities of the Plain where Magdalena meets her inevitable, morbid fate after being butchered by her pimp's guard. She was meant to have stayed where she belonged. If not in a brothel, in a morgue, then. She is symbolically framed or trapped forever in a picture, which is not abandoned but turned face down. The captain shows the autopsy photo of Magdalena to Billy Parham and then returns it "to the tray face down" [McCarthy 1998: 242]. In No Country for Old People, Carla Jean encounters her deadly destiny personified in Anton Chigurh. He kills her, just to keep the promise given to her husband in case he does not cooperate nor return the money. After having retrieved the booty and assassinating Moss, Chigurh shoots Carla Jean. Her fate is sealed the moment the killer finds her two pictures and keeps them as the prelude of her killing.

In Child of God, all the women are dead. In fact, Lester murders his female victims precisely to make them his love objects as part of his necrophiliac practices. Girls function as perfect objects: mute, willing to coexist on the lover's terms, easily discarded when futile. When exhumed, their corpses encapsulate the nature of degradation, being "covered with (...) a pale gray cheesy mold” and dripping "a gray rheum" [McCarthy 1973: 198]. 


\section{Women substitutes or confinement and relegation from the stories}

In All the Pretty Horses, as in the other trilogy instalments, the circuit of male desire takes two paths. The first involves a determination to find the right way to chase the male motif of action; the second, to combine the first motif with the presence of beloved ones. John Grady's objects of desire are different girls. From a West Texas school girl, through a young Mexican debutante, to an epileptic prostitute, they become disturbingly replaceable. The descriptions of both Alejandra and Magdalena are bound through their long black hair and their blue dresses [McCarthy 1992: 94, 123, 141; McCarthy 1998: 6, 229]. Alejandra seems to be a prelude to the ensuing encounter with Magdalena. In her prophetic dream she sees the inevitable termination of John's struggle to win his love. "They carried you through the streets of a city I'd never seen. It was dawn. The children were praying. Lloraba tu madre. Con mas razon tu puta" [McCarthy 1992: 252; Your mother was weeping. More to the point your whore], a scene that occurs at the end of Cities of the Plain. Dianne Luce implies that Alejandra might be a substitute for Mary Catherine, who left John for an older boy. Magdalena, in turn, described during the first meeting as a "young girl of no more than seventeen and perhaps younger" who "fussed with the hem of her gaudy dress like a schoolgirl" [McCarthy 1992: 6], relates to Mary Catherine, like a vicious circle of John's fate. "She was so goddmaned pretty, bud" John Grady tells Billy [McCarthy 1992: 259]. However, he never calls Magdalena by her name in the final pages of the novel. This is, again, an attempt to remove all the women from his life, as in all of McCarthy's books.

In The Crossing the only fully developed female character is not a woman at all, but a pregnant she-wolf, who dies in the first part of the narrative - again, to follow the misfortune of other females. Billy Parham, the protagonist, who has dreamed of wolves, after a series of trials, traps one and hogties it, muzzles it, leashes it with a catch rope, and sets off south across the unfenced land to return it to the mountains of Mexico. The scene of overpowering the she-wolf resembles unfavourably a masculine manner, where Billy tries to subdue her with the use of physical strength that uncomfortably recalls rape: "It ain't no use to fight it," he tells her, "You ain't got no damn sense" [McCarthy 1994: 56-57]. After that, "he sat stroking her. Then he reached down and felt her belly. She struggled and her eyes rolled widely. He spoke to her softly. He put the flat of his hand between her warm and naked teats. He held it there for a long time" [McCarthy 1994: 74]. Before her death, the she-wolf faces increasingly deadly forms of restraint, 
from the wolf traps set early in the novel, to the muzzle, the carretero's tent where a ten-centavo admission is charged to see her [McCarthy 1994: 104], and the dogfight pit where she is chained to a stake. Finally, Billy himself kills the wolf and encloses her and the unborn pups: "[H]e buried them all and piled the rocks over them" [McCarthy 1994: 129].

Like the she-wolf in The Crossing, in Cities of the Plain Magdalena also moves through a series of increasingly fatal forms of confinement. She is placed in the White Lake brothel and can be seen restrained during her epileptic seizures in two different scenes; in the first, the criada forces a piece of broomstick between Magdalena's teeth [McCarthy 1998: 72], in an act reminiscent of Billy's attempt to subdue the she-wolf by muzzling her with a stick in her mouth. During the second seizure, Tiburcio forces a leather belt between her teeth. The final chapters of the novel show her moving from the hospital room with a concrete ceiling where she is "strapped to a steel table" [McCarthy 1998: 208], to Eduardo's bedroom with its "small barred window" [McCarthy 1998: 213], to the morgue with its overhead light "covered with a small wire basket" [McCarthy 1998: 229].

Magdalena as a character in the novel constitutes a viable metaphor for women's fate in McCarthy's stories, for she is restrained, reduced, and at long last, relegated to the edges of existence. Although Magdalena receives more narrative attention than any other female in McCarthy's work, she is, as the blind maestro says, "at best a visitor (...). She does not belong here. Among us," [among men] [McCarthy 1998: 81]. She, as well, has to eventually give way to an omnipresent femininity without women.

Cormac McCarthy's attitude toward women is disturbing. In one interview, after being asked about the absence of women in his works, he simply replied: "women are tough (...). I don't think men understand women. They find them very mysterious" [Winfrey 2007]. Whether the author meant incomprehensible or the compound nature of women in male perception, the word "mysterious" may, as well, have negative connotations and refer to something dangerous, or cryptic. After studying McCarthy's narratives it is hard not to associate the writer with a crypto-misogynistic tendency to mystify women's existence. Most of the novels are unanimous in their story line. They are about men, they prefer men, they are about men alone, and men together, they are about men protected by men, they are about manly friendship and bonds. Women are set against men in nearly total absence, depicted subjectively, marginalized, exterminated. Although McCarthy's would-be misogyny seems to be of the ancient Melvillian kind, he does not express an active contempt for women - merely a complete 
disregard for female existence. Clearly seen in many story lines in Cormac McCarthy's novels, the exclusion or expulsion of female characters from his fiction makes women not only vulnerable but also undergo a certain literary discrimination. With male dominance in every plot, women stand no chance to develop decently. Their femininity is discredited by being pictured in either a simplified manner or degraded and closed in a frame of uncomfortable stereotypes. It seems that this rather negative, or as might be claimed, misogynistic tendency of portraying female characters, unveils McCarthy's unfavorable stance towards women. However, intricately woven plots with complicated structures of male protagonists, put a more distinct burden over men's shoulders; thus, this is the way they face all the consequences of their dominance over the world's definition of gender.

Yet, changes have to be brought forward and embrace social issues of class and gender in literature as well. On the one hand, what male and female stand for at the present time is altering the definition of society. There are changing roles that are quite visible in life, at the workplace, in art. However, social, and therefore literary, modifications take time. The concept of literature being a reflection of reality appeals to many writers, so narratives should mirror social manners, the changing roles of females, their social and emotional life. There is hope they will be reflected in Cormac McCarthy's long-waited Passenger.

\section{Bibliography}

Arnold E. T. (1999), Perspectives on Cormac McCarthy, Jackson, UP of Mississippi.

Bradfield S. (1993), When The Mystery is That There is No Mystery, "Independent", 17.04.1993, https://www.independent.co.uk/arts-entertainment/books/book-reviewwhen-the-mystery-is-that-there-is-no-mystery-all-the-pretty-horses-cormacmccarthy-1455726.html, [25.05.2016].

Fisher-Wirth A. (2002), Abjection and The Feminine in "Outer Dark", Albuquerque, University of New Mexico Publishing.

Hage E. (2010), Cormac McCarthy. A Literary Companion, Jefferson, North Carolina, McFarland \& Company, Inc., Publishers.

Hass R. (1994), Travels with a She-Wolf, "The New York Times on The Web", 12.07.1994, http://movies2.nytimes.com/books/98/05/17/specials/mccarthy-crossing.html, [04.05.2016].

Kristeva J. (1982), The Powers of Horror: An Essay on Abjection, New York, Columbia UP.

Luce D. C. (2009), Reading the World: Cormac McCarthy's Tennessee Period, Columbia, University of South Carolina Publishing. 
McCarthy C. (1965) The Orchard Keeper, New York, Vintage.

McCarthy C. (1968) Outer Dark, New York, Vintage.

McCarthy C. (1973) Child of God, New York, Vintage.

McCarthy C. (1985) Blood Meridian: Or the Evening Redness in the West, New York, Vintage.

McCarthy C. (1989) Suttree, New York, Vintage.

McCarthy C. (1992) All the Pretty Horses, New York, Vintage.

McCarthy C. (1994) The Crossing, New York, Vintage.

McCarthy C. (1998) Cities of the Plain, New York, Vintage.

McCarthy C. (2005) No Country for Old Men, New York, Vintage.

McCarthy C. (2006) The Road, New York, Vintage.

Sullivan N. (2000), The Evolution of the Dead Girlfriend Motif in "Outer Dark" and "Child of God", [in:] R. Wallach (ed.), Cormac McCarthy: Myth, Legend, Dust, Manchester, Manchester UP: 68-77.

Sullivan N. (2001), Boys will be Boys, Girls will be Gone: The Circuit of Male Desire in Cormac McCarthy's Border Trilogy, [in:] E.T. Arnold, D.C. Luce (eds.), A Cormac McCarthy Companion: The Border Trilogy, Jackson, UP of Mississippi: 228-252.

Winfrey O. (2007), Oprah Winfrey Show, ABC, 06.06.2007.

\section{SUMMARY}

\section{Discredited Female Characters, or "Gone With the Women". A Descriptive Essay of Marginalized Femininity in Cormac McCarthy's Selected Novels}

Cormac McCarthy, one of the greatest contemporary novelists in America, glorifies the male world, giving women minor importance. In one interview, after being asked about the absence of women in his works, he replied "women are tough (...). I don't think men understand women. They find them very mysterious". The word "mysterious" may have a negative connotation and would refer to something dangerous, scary, suspicious. After studying McCarthy's works, it is hard not to associate the writer with an unfavourable, indeed, misogynistic tendency to mystify women and female sexuality. Not only does he characterize women as degraded characters, often relegated to insignificant duties, but presents them as symbols of trouble, misfortune, death. The novelist praises the male bond, whereas the female-male relationship perishes. This essay contextualizes his male dominance over female characters, points out the diminished role of women, as well as outlining several recurring patterns of portraying them as bad mothers, subservient characters, whores, and their association with danger and death.

KEYWORDs: Cormac McCarthy, dominance, female characters, marginalization, misogyny 